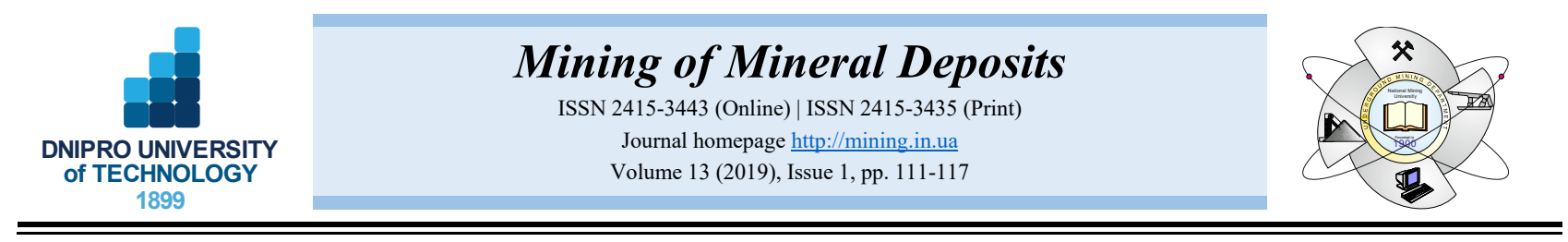

UDC 622.014 .2

https://doi.org/10.33271/mining13.01.111

\title{
PROSPECTIVE TENDENCIES OF COAL MINING RISK MANAGEMENT
}

\author{
M. Ilyashov ${ }^{1}$, I. Diedich ${ }^{1 *}$, V. Nazimko

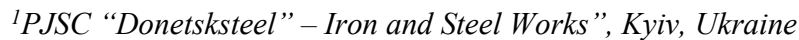 \\ ${ }^{2}$ Institute for Physics of Mining Processes of the National Academy of Sciences of Ukraine, Dnipro, Ukraine \\ *Corresponding author: e-mail ivan.dedich@donetsksteel.com.ua, tel. +380502472348
}

\begin{abstract}
Purpose. The main purpose is to identify underground coal mining risks as well as approaches for their reasonable and efficient management taking into consideration internal production reserves in order to improve technological processes' efficiency and operational efficiency.

Methods. In order to achieve a target goal, the paper highlights and analyzes production processes involving the highest risk level. Methods of analogous risk characteristics, systematic approach towards developing a system of coal mining risk management as well as methods of distributed control have been applied to develop risk management innovative methods.

Findings. The reasons stipulating coal mining risks based upon geologic, technologic, and economic aspects of mining practice as well as imperfection of human psychology, have been defined. Attention is drawn to the necessity to involve efficient counterweights relying upon additional bonuses for detecting violations, innovative trainings, and training of personnel to prevent safety inhibitions. A matrix structure has been demonstrated as the optimum structure for risk management, which should implement the idea of distributed control. Combination of effective operative information support with a system of open communication helps to develop conditions to change attitude of participants of underground coal mining towards risks to ensure safety.
\end{abstract}

Originality. For the first time, the reasonability of combining matrix structure with distributed risk management has been demonstrated as well as substitution of unifactor discrete cumulative characteristic of explosion probability or methane ignition for analogous characteristic, dependent on several factors.

Practical implications. Performance assessment throughout coal mines' operations improves reliability and safety of production processes and mining practices as well as provides for proactive risk management.

Keywords: underground coal mining, risks, proactive management, distributed control structure

\section{INTRODUCTION}

Specific feature of underground coal mining is determined by means of high uncertainty conditions that originate a number of risks (Cox, 2012). Generally, risk factors are specified in external macroeconomic and branch environment within the enterprise competence as well as in terms of possibilities effectively applying available resources (Fan \& Yuan, 2016). Analysis shows that few risk factors are critical and therefore are hard to control (Verma \& Chaudhari, 2016).

The number of risk factors depends heavily upon enterprise's management team competence, its ability to form adequately strategic goals and manage their achievement as well as upon skills to develop and implement innovative projects, manage both human and financial resources, and capabilities to run effective operational management of productive processes (Volkov \& Horoshkova, 2018; Domínguez, Martínez, Piñón Peña, \& Rodríguez Ochoa, 2019). Risk level can also be decreased significantly through skillful and economical use of material resources, equipment, and capital stock of the enterprise (Domingues, Baptista, \& Diogo, 2017). In this context, management and control of mining safety play an important role in underground mining risk management (Chen, Qi, \& Feng, 2013; Wang, Cheng, \& Liu, 2014; Gao, Fu, \& Nieto, 2015).

The paper is intended to demonstrate approaches towards reasonable and operative management of underground coal mining risks taking into consideration internal production reserves.

(C) 2019. M. Ilyashov, I. Diedich, V. Nazimko. Published by the Dnipro University of Technology on behalf of Mining of Mineral Deposits.

This is an Open Access article distributed under the terms of the Creative Commons Attribution License (http://creativecommons.org/licenses/by/4.0/),

which permits unrestricted reuse, distribution, and reproduction in any medium, provided the original work is properly cited. 


\section{FACTORS THAT INCREASE RISKS OF UNDERGROUND MINING}

Webster's dictionary interprets risk as a possibility to lose or damage something; Oxford dictionary understands risk as a possibility to face danger or a possibility to suffer from damaging or losing something. ISO 31000:2018 Standard interprets risk concept in a much broader way implying that a risk is an effect which makes a desired goal to be an uncertain one. The effect may be both positive and negative, for instance, while generating losses or creating, on the contrary, favourable conditions, which were not considered previously. Therefore, traditional approach to risks, which was focused on events, can be reoriented to the specific potential. That makes it possible to substitute reactive paradigm of risk management for proactive one. As for the quantitative risk estimation, it can be performed integrally through risk probability assessment in terms of economic, social, reputational factors and image' damage resulting from the occurrence of an event provoking the risk.

High danger environment of mining operations, connected with risks of unstable rock caving (especially in the context of transition zones of geological faults), methane and coal dust bursts (ignitions), coal and gas outbursts, spontaneous firing of coal seams etc. are the specific features of underground coal mining risks (Wojtecki \& Konicek, 2016; Zapletal, Koudelkova, Zubicek, Kral, $\&$ Mokrosova, 2018). Thus, the problem of underground coal mining risk management is closely related to the problem of mining safety.

The risks are stipulated by significant natural geological uncertainty including seismicity, uncertainty of operating schedules, underground space constraint, economic situation, imperfection of human psychology, etc. (Drzewiecki \& Piernikarczyk, 2017; Gayko, Matviichuk, Biletskyi, \& Saluga, 2018). For instance, considerable uncertainty of parameters at the uncontrolled worked out area leads to the risks of gas contamination of underground mine workings and underground space constraint. Furthermore, it leads to an intensive manifestation of rock pressure that results in decreased geometry of section of mine workings integrating the increased risks of reliable ventilation, transport and mining safety. (Lozynskyi, Saik, Petlovanyi, Sai, \& Malanchuk, 2018; Tripathy \& Ala, 2018).

\section{FEATURES OF ARISING RISKS CONNECTED WITH COAL MINING PROCESSES}

Safety control under the conditions of dangerous atmosphere is one of the acute problems connected with extra-hazardous risks. Disbalance in the allowable methane concentration is one of the most common risk event within technological chain of underground mine workings. It is known that local zones arise frequently in a long stope where concentration of methane in the air flowing the stope either exceeds permissible, being $1 \%$, or during short periods of time may be equal to stoichiometric mixture concentration or even go beyond it. Long time ago, experts put forward a rhetorical question: is it sufficient measure to control methane concentration within longwall-air drift junction? It is common knowledge that methane-air explosion development needs some time, certain critical volume of the mixture as well as its certain concentration. A process of methane-air mixing is highly chaotic and turbulent; it should involve interactive control both temporally and spatially in terms of the whole volume of the mine working. It is no secret that mining often takes place under the conditions of more than $1 \%$ methane-air mixture concentration which is violation of safety rules. Miners understand through insight that explosion probability increments gradually being a composite function of time, gas concentration, and spatial dimension as well as such a probability that a spark (temperature) is sufficient to provoke origination of chain reaction of explosion or spark ignition within a critical point directly. However, miners often "play roulette" keeping their fingers crossed; precisely such a violation becomes a reason of large-scale accidences. Practices show that in the context of $99 \%$, when one per cent limitation of methane concentration was violated, they did not result in explosion. Thus, the risk may be justified. The fact can explain paradoxical communication between risks and safety: the safer human is, the greater risk appetite is. The paradigm is especially topical while solving a problem of adhesion to allowable methane concentration within return ventilation air.

Principal defect of the available normative explosiveness model with one per cent threshold is its discrete or multistage nature (Fig. 1). The normative model involves too high safety margin tempting miners to risk. The worse thing is that after one percent threshold is exceeded (dark arrow in Fig. 1) and Safety rules are violated, miners work under the conditions of complete uncertainty losing every possible chance to control the current situation.

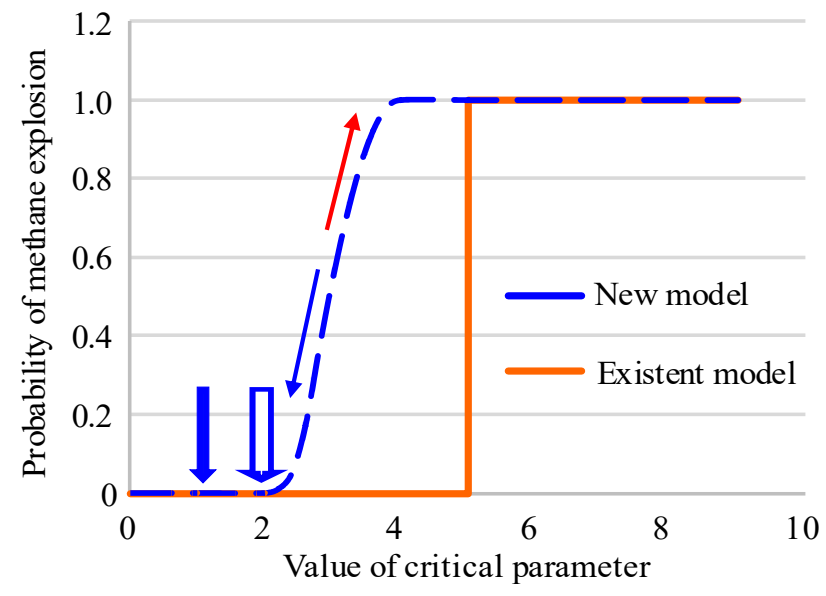

Figure 1. Cumulative distributions of explosion probability

To avoid risks of methane-air mixture explosion, it is expedient to substitute discrete characteristic of explosion risk for smooth and continuous one taking into consideration a process of gradual transition from safety state to the most dangerous situation when the explosion will happen surely (Ilyashov, 2018). Broken curve shows a new probabilistic cumulative characteristic. In this context, abscissa axis has been gauged not in the methane concentration percentage but in the values of a complex characteristic taking into consideration methane concentration as well as state of sources of possible explosion initiation, air flow velocity, dust content, and other factors effecting explosion possibility heavily. 
Getting an idea of smoothness of explosion probability or methane ignition dependence on the current value of the main factors (dashed line) effecting explosion possibility, miners will understand that the reserve to prevent risks is far less which will suppress their risky actions. Moreover, it is necessary to develop such a safety system which will provide monitoring of the current situation trend prompting operators: situation worsens (inclined up arrow) or betters (inclined down arrow). It is expedient to place signaling and telecommunicating devices within critical points (i.e. within coal shearer, conveyor drives, and air drift-longwall junction) which will use signal intensity, and its tone to inform on danger level. Such a simple measure will have essential psychological effect on miners obtaining information concerning their risky actions. Hence, the system will switch off electricity as it is done within a system basing upon the index of one per cent methane concentration threshold. The deenergization will take place at the moment when explosion probability (instead of concentration methane at $>1 \%$ level!) starts differing from 0 (light arrow). Even if the system is deenergized, it continues informing workers on the further situation development - positive or dangerous. Hence, if somebody makes decision to block deenergizing, the system will go on informing on the level of danger.

Determination of threshold values with lesser safety factor will not result in the objective increased explosion danger; miners will rather understand that the alarm devices operate objectively and if the warning is neglected, emergency situation may be unavoidable (Pivnyak \& Shashenko, 2015). Such models offer new opportunities to correct imperfect explosion-risk methods and criteria; first, it concerns the same one per cent methane concentration level. In its simplest version, the model can be developed on the basis of artificial neural network having at least three input neurons: for the current concentration of methane-air mixture input; for probability of explosion initiator origination; and probability that methane concentration will be dangerous in the neighbourhood of the initiator. To improve the model, it is necessary to add inputs for coal dust concentration consideration as well as other factors which may multiply explosion chance. Output neuron will calculate explosion probability shown in terms of the dashed smooth curve in Figure 1. The key problem is in the availability of data to train the model. The data of results of investigation of accidents, connected with methane explosions and ignitions, and tests with mixtures for their explosion risks are the most reliable.

Taking into consideration the fact that the problem of methane explosion and ignition involves essential psychological component, the factors, which would further mining safety, have been analyzed relying upon risk management principles. Experts believe that psychological factor or human factor, involved in the solving the problem of methane explosion prevention, is greatly underestimated. It has been confirmed lately by means of numerous publications where it is said that importance of human factor is not great. To a large extent, it plays a key role in the formation of explosive situation in mine workings. Effect of the factor is not only significantly underestimated; but rather suppressed. Moreover, focus is shifted to technological factors or geological ones. The problem is complicated since violation of safety rules may be a collective solution of a shift operating currently in a stope; sometimes, it results from a silent assent of the mine authorities. Against the background of large safety factor of the one per cent methane concentration threshold, material remuneration (i.e. profit, bonus for plan overachievement) is a powerful risk stimulus for participants of coal mining and workers have additional fear of job loss if they oppose taking life risk. High degree of risk tolerance is shaped; miners get accustomed to operate under conditions where they have to ignore the risks and danger.

In such a case, methodology to manage risks proposes to attract a number of efficient counterbalances. World practices apply such methods. For instance, in the USA, health and safety executive encourages staff to inform him or her about violations; moreover, trade unions or government reward financially the person. From the ethical viewpoint, such a tactic is quite acceptable in a society since safety rules violations endanger lives of underground workers directly and immediately. Not without a reason, wise Sir Churchill noted that safety should be paid away, and its nonavailability should be paid for.

There is also a number of other counterbalances to limit the violations. An important role is played by instructions and trainings to promote knowledge attitude and safety practices of all participants of coal mining process as well as inform about risk probabilities, dangers, and regularities resulting in danger origination.

There is one more important reserve, hardly used in coal mining industry: its management is very centralized. However, the centralization, acting positively when it is required to concentrate efforts, resources, and energy to perform certain task, is a reason for safety violations giving rise to unreasonable serious risks. In this connection, it is expedient to introduce elements of distributed control coal mining processes (Nazymko, 2014). This practice will help a greater number of employees to control coal mining processes and, if it is necessary, to interfere at the right time and withdraw the miner from the working area when dangerous situation, characterized by a certain risk degree, is initiated. The above can be compared to the possibility of any passenger to stop a train by means of emergency brake if danger originates. It is also important for a worker to be able to inform promptly about safety violations or respond actively to the violations, and his or her information shall be registered and verified by authorities. In this context, it is necessary to perform constant monitoring of indices of explosiveness (i.e. methane concentration within each point of drifting site or mining site where it is measured; state of potential ignition sources etc.).

Smooth operation of a stope is also an important measure to reduce risks of methane-air mixture. Currently, stopes operate basically on the verge of a load being permissible as for the gas factor (Kasimov, Bokiy, \& Nazimko, 2007). Precisely such a situation tempts miners to be on the night shifts with the excess of permissible level of methane concentration. Even if the violation does not result in explosion, delayed explosion risks arise depending on the worked-out area gas content.

Therefore, there are certain technological problems which should be considered from the viewpoint of toler- 
ated risks since they are not related to the fatality risks. The problems have to be solved starting from the definition of the risk level based upon which optimum mining parameters are subsequently defined and selected; for instance, from the viewpoint of minimization of risks of breaking of objects being undermined (Luo, 2015). The risk level should be selected as that, being proportional to the predicted value of potential losses. In this context, even the level of admissible internal economic risks as well as image risks has to decrease along with the increase in the efficiency and competitiveness of operations and the whole enterprise.

One more risk factor is stipulated by transition of zones being dangerous due to rock pressure manifestations. As a rule, boundaries between dangerous zones, and zones, being safe from the viewpoint of mining operations, are dissolved both in space and time. Thus, the measures, intended to control and improve safety, should vary along with the movement through the transition zone; and extent of the measures should depend upon the predetermined risk. That will help to distribute the risk uniformly while optimizing expenditures connected with the transitions through dangerous zones.

Technology to drive development mine workings and their maintenance is rather important for the process of risky situation formation (Ilyashov, 2011; Mohammadi, 2017). First, development mine workings are significant share of capital assets of mining enterprises. Hence, their failure results in significant economic loss inclusive of all negative consequences. Second, development mine workings are necessary for the formation of a line of stopes thus being fundamental in terms of underground mining hierarchy. For instance, if mine workings lose their stability that results in worsening of hoisting conditions and ventilation conditions; moreover, it also results in risks for safe staff movement or their evacuation if emergency situation. Consequently, the preserved stability of a belt entry behind the longwall within a zone of dynamic displacements makes it possible to provide progressive straight-through scheme to ventilate a stope as well as to have the opportunity to reuse the mine working as an air way (Ilyashov, 2011). Such an effect is followed by a number of essential sequences and results. First, it helps to solve a problem of limitation of load on the longwall in terms of gas factor; second, significant economic effect is involved owing to extra coal mining and owing to savings resulting from air way driving. Third, favourable safety conditions are created for underground mining. Thus, risks connected with possible methane-air flow, stability loss of ventilation system, break of transportation chain and delivery of materials etc. reduce.

Another important component of the system to manage production risks within stopes are technological elements, and elements of control of mechanisms, i.e. stope advance, operation schedules of coal shearer, and powered section shifting, means to support junction and conveyor fastening. It is essential for risk management system to be built-in and integrated into a general system of coal mining control to be open for all the related parties. Moreover, it should involve constant improvement based upon active feedback among all participants as well as human factor on which the majority of cases of safety violations depend and risky situations happen. In other words, employees of each level should know that safety is continuous process aimed at improvement and adaptation to constantly varying conditions.

\section{ASPECTS TO FORM RISK MANAGEMENT SYSTEM AT COAL MINING ENTERPRISES}

Implementation of the above mentioned approaches should involve the development of a system to manage risks. The system has to be integrated into a general system to control underground coal mining including certain technological operations concerning preparation of reserves, their extraction, and maintenance activities. It is necessary to substitute reactive paradigm of risk management for proactive one. From the managerial viewpoint, it is required to make revolutionary changes by means of introducing the ideas of distributed management into the centralized system of production and risk management (Nazymko, 2014). That will help to involve all participants and related parties (from authorities to auxiliary personnel) into risk management processes. The paradigm of distributed management makes it possible to radically change attitude to risks from compulsory to initiative when all the participants of coal mining recognize the safety performance problems as necessary activities providing both efficiency and mining safety.

Such a paradigm can be successfully implemented owing to the comprehensive approach:

a) selection of rational structure to manage risks;

b) integration of risk management motivation' elements into a planning process;

c) development of employees' new attitude towards risk management, capacity building, training, knowledge and skills evaluation, monitoring, assessment, motivation;

d) information support of operating processes to manage risks and communications.

Development of new attitude of employees towards risk management is a multidimensional challenge that is beyond the scope of this article. It is important to note that it is meant for a long time period, phasing, and succession. Further, it should be emphasized that everyone will reorient his or her attitude personally including authorities and external coal mining participants who to a greater or lesser extent are interested in achieving a defined final goal (i.e. manufacturers of mining equipment, mine builders, customer engineers etc.).

Information support and communications' development among management process participants, closely connected with the former, are the essential components helping to successfully solve the problem of risk management. Communication system relies upon open database, and state-of-the-art technical aids. Proactive risk management is impossible without operative and reliable information concerning real state of equipment, mine workings, and transportation chains. An efficient information support system can be developed while based upon distributed management combination with its matrix structure (Fig. 2). 
Domínguez, C.R., Martínez, I.V., Piñón Peña, P.M., \& Rodríguez Ochoa, A. (2019). Analysis and evaluation of risks in underground mining using the decision matrix riskassessment (DMRA) technique, in Guanajuato, Mexico. Journal of Sustainable Mining, 18(1), 52-59. https://doi.org/10.1016/j.jsm.2019.01.001

Drzewiecki, J., \& Piernikarczyk, A. (2017). The forecast of mining-induced seismicity and the consequent risk of damage to the excavation in the area of seismic event. Journal of Sustainable Mining, 16(1), 1-7. https://doi.org/10.1016/j.jsm.2017.05.001

Fan, B., \& Yuan, Y. (2016). Constructing an assessment index system for strategic risk management in coal science and technology enterprises. International Journal of Mining Science and Technology, 26(4), 653-660. https://doi.org/10.1016/j.ijmst.2016.05.018

Gao, Y., Fu, G., \& Nieto, A. (2015). A comparative study of gas explosion occurrences and causes in China and the United States. International Journal of Mining, Reclamation and Environment, 30(4), 269-278. https://doi.org/10.1080/17480930.2015.1043770

Gayko, H., Matviichuk, I., Biletskyi, V., \& Saluga, P. (2018). Forecast assessment methods of geological environment promotion for the construction of urbanistics subjects. Visnyk of V.N. Karazin Kharkiv National University - Series Geology Geography Ecology, (48), 39-51. https://doi.org/10.26565/2410-7360-2018-48-03

Iliashov, M.A. (2011). Reuse of entries is an effective way to increase competition of the mine fond. Coal of Ukraine, (1), 22-26.

Ilyashov, M.O. (2018). Numerical assessment as a basis of rick control during underground coal extraction. Coal of Ukraine, (7-8), 23-31.

Kasimov, O.I., Bokiy, B.V., \& Nazimko, V.V. (2007). Methane desorption into coalmine entries. Transactions of UkrNIMI NAS Ukraine, (1), 232-238.

Lozynskyi, V., Saik, P., Petlovanyi, M., Sai, K., \& Malanchuk, Y. (2018). Analytical research of the stress-deformed state in the rock massif around faulting. International Journal of Engineering Research in Africa, (35), 77-88. https://doi.org/10.4028/www.scientific.net/jera.35.77

Luo, Y. (2015). An improved influence function method for predicting subsidence caused by longwall mining opera- tions in inclined coal seams. International Journal of Coal Science \& Technology, 2(3), 163-169. https://doi.org/10.1007/s40789-015-0086-x

Mohammadi, M., Hossaini, M.F., \& Bagloo, H. (2017). Rock bolt supporting factor: rock bolting capability of rock mass. Bulletin of Engineering Geology and the Environment, 76(1), 231-239. https://doi.org/10.1007/s10064-015-0785-y

Nazymko, V.V. (2014). Models and methods for prompt control of projects. Saarbrücken: Palmarium Academic Publishing.

Pivnyak, G.G., \& Shashenko, O.M. (2015). Innovations and safety for coal mines in Ukraine. Naukovyi Visnyk Natsionalnoho Hirnychoho Universytetu, (6), 118-121.

Tripathy, D.P., \& Ala, C.K. (2018). Identification of safety hazards in Indian underground coal mines. Journal of Sustainable Mining, 17(4), 175-183. https://doi.org/10.1016/j.jsm.2018.07.005

Verma, S., \& Chaudhari, S. (2016). Highlights from the literature on risk assessment techniques adopted in the mining industry: A review of past contributions, recent developments and future scope. International Journal of Mining Science and Technology, 26(4), 691-702. https://doi.org/10.1016/j.ijmst.2016.05.023

Volkov, V., \& Horoshkova, L. (2018). Management of lean mining and use of mineral resources of Ukraine. Visnyk of Taras Shevchenko National University of Kyiv. Geology, 3(82), 60-65.

https://doi.org/10.17721/1728-2713.82.08

Wang, L., Cheng, Y.-P., \& Liu, H.-Y. (2014). An analysis of fatal gas accidents in Chinese coal mines. Safety Science, (62), 107-113. https://doi.org/10.1016/j.ssci.2013.08.010

Wojtecki, Ł., \& Konicek, P. (2016). Estimation of active rockburst prevention effectiveness during longwall mining under disadvantageous geological and mining conditions. Journal of Sustainable Mining, 15(1), 1-7. https://doi.org/10.1016/j.jsm.2016.04.003

Zapletal, P., Koudelkova, J., Zubicek, V., Kral, T., \& Mokrosova, A. (2018). A new method of gas drainage as a solution for dangerous phenomena in underground coal mines. Rudarsko Geolosko Naftni Zbornik, 33(1), 7-13. https://doi.org/10.17794/rgn.2018.1.2

\section{ПЕРСПЕКТИВНІ НАПРЯМИ УПРАВЛІННЯ РИЗИКАМИ ВУГЛЕВИДОБУТКУ}

\section{М. Ільяшов, І. Дєдіч, В. Назимко}

Мета. Виявлення ризиків підземного вуглевидобутку, а також підходів до їх раціонального та оперативного управління з урахуванням внутрішніх резервів виробництва для підвищення ефективності технологічних процесів і операцій.

Методика. Для досягнення поставленої мети в роботі виділені та проаналізовані виробничі процеси, що володіють найбільш високим ступенем ризиків, а для розробки інноваційних шляхів управління ризиками використані методи аналогових характеристик ризику, системний підхід до створення системи керуванням ризиками вуглевидобутку, методи розподіленого управління.

Результати. Надано характеристику причин, що визивають ризики вуглевидобутку, заснованих на геологічних, технологічних та економічних аспектах гірничого виробництва, а також викликаних недосконалістю людської психології. Акцентовано увагу на необхідності залучення ефективних противаг, заснованих на додатковому преміювання за виявлення порушень, на інноваційних тренінгах і навчанні персоналу для запобігання порушенню безпеки. Показано, що оптимальною структурою управління ризиками $є$ матрична, яка повинна реалізувати принцип розподіленого управління. Поєднання ефективного оперативного інформаційного забезпечення з системою відкритої комунікації дозволяє створити умови для зміни ставлення учасників процесу підземного вуглевидобутку до ризиків для забезпечення безпеки.

Наукова новизна. Вперше показана доцільність комбінування матричної структури і розподіленого управління ризиками, а також заміни однофакторної дискретної кумулятивної характеристики ймовірності вибуху або спалаху метану на аналогову, що залежить від декількох факторів. 
Практична значимість. Врахування результатів роботи при функціонуванні вугільних шахт підвищує надійність і безпеку виробничих процесів та операцій видобутку, а також забезпечує проактивне управління його ризиками.

Ключові слова: підземний вуглевидобуток, ризики, проактивне управління, розподілена структура управління

\section{ПЕРСПЕКТИВНЫЕ НАПРАВЛЕНИЯ УПРАВЛЕНИЯ РИСКАМИ УГЛЕДОБЫЧИ}

\section{М. Ильяшов, И. Дедич, В. Назимко}

Цель. Выявление рисков подземной угледобычи, а также подходов к их рациональному и оперативному управлению с учетом внутренних резервов производства для повышения эффективности технологических процессов и операций.

Методика. Для достижения поставленной цели в работе выделены и проанализированы производственные процессы, обладающие наиболее высокой степенью рисков, а для разработки инновационных путей управления рисками использованы методы аналоговых характеристик риска, системный подход к созданию системы управлением рисков угледобычи, методы распределенного управления.

Результаты. Дана характеристика причин, вызывающих риски угледобычи, основанных на геологических, технологических и экономических аспектах горного производства, а также вызванных несовершенством человеческой психологии. Акцентировано внимание на необходимости задействования эффективных противовесов, основанных на дополнительном премировании за выявление нарушений, на инновационных тренингах и обучении персонала для предотвращения нарушения безопасности. Показано, что оптимальной структурой управления рисками является матричная, которая должна реализовать принцип распределенного управления. Сочетание эффективного оперативного информационного обеспечения с системой открытой коммуникации позволяет создать условия для изменения отношения участников процесса подземной угледобычи к рискам для обеспечения безопасности.

Научная новизна. Впервые показана целесообразность комбинирования матричной структуры и распределенного управления рисками, а также замены однофакторной дискретной кумулятивной характеристики вероятности взрыва или вспышки метана на аналоговую, зависящую от нескольких факторов

Практическая значимость. Учет результатов работы при функционировании угольных шахт повышает надежность и безопасность производственных процессов и операций добычи, а также обеспечивает проактивное управления ее рисками.

Ключевые слова: подземная угледобыча, риски, проактивное управление, распределенная структура управления

\section{ARTICLE INFO}

Received: 22 November 2018

Accepted: 11 March 2019

Available online: 19 March 2019

\section{ABOUT AUTHORS}

Mykhaylo Ilyashov, Doctor of Technical Sciences, Head of the Directorate for Safety and Ecology, PJSC "Donetsksteel" Iron and Steel Works”, 30 Lesi Ukrainky Blvd, 01133, Kyiv, Ukraine. E-mail: ivan.dedich@donetsksteel.com.ua

Ivan Diedich, Candidate of Technical Sciences, Manager of the Directorate for Safety and Ecology, PJSC "Donetsksteel" Iron and Steel Works", 30 Lesi Ukrainky Blvd, 01133, Kyiv, Ukraine. E-mail: ivan.dedich@,donetsksteel.com.ua

Victor Nazimko, Doctor of Technical Sciences, Principal Inverstigator of the Ground Control Department, Institute for Physics of Mining Processes of the National Academy of Sciences of Ukraine, 15 Simferopolska St, 49005, Dnipro, Ukraine. E-mail: victor.nazimko@gmail.com 